\title{
The Effectiveness of Rabies Control Program in West Bandung Regency, West Java, Indonesia
}

\author{
Okta Wismandanu \\ Study Program of Veterinary \\ Medicine \\ Faculty of Medicine Universitas \\ Padjadjaran \\ Bandung, Indonesia \\ okta.wismandanu@unpad.ac.id
}

\author{
Roostita L Balia \\ Study Program of Veterinary \\ Medicine \\ Faculty of Medicine Universitas \\ Padjadjaran \\ Bandung, Indonesia \\ roostita@gmail.com
}

\author{
Wiwin Aprianti \\ Animal Health Division of \\ Fisheries and Animal Husbandry \\ Services Office of West Bandung \\ Regency \\ Bandung Barat, Indonesia \\ wiwinapriantidrh@yahoo.com
}

\author{
Nirowati \\ Animal Health Division of \\ Fisheries and Animal Husbandry \\ Services Office of West Bandung \\ Regency \\ Bandung Barat, Indonesia \\ nirothea675@gmail.com
}

\begin{abstract}
Rabies is one of the most important zoonotic disease in Indonesia that need to be eliminate. The rabies control/elimination program has been undertaken by local government to achieve 2023 West Java Province rabies free. The aim of this study is to measure the effectiveness of rabies control program in West Bandung Regency. We modified RabiesEcon, the mathematical of dog-dog and dog-human rabies transmission to simulate rabies control program in West Bandung Regency. The human population data, dog population and the rabies control program (dog vaccination, postexposure prophylaxis (PEP) and dog population control program data) are using to this model based on the data from local government. We build 3 optional control program: no vaccination (Scenario 1), annual vaccination of $70 \%$ of dogs population (Scenario 2) (Based on WHO recommendation for rabies elimination) and $35 \%$ of dogs vaccinated program biannually (Scenario $3)$. We estimate the number of preventable dog rabies and the cost of DALY averted due to this disease. We estimate the accumulative rabies cases in 5 years' period of the program will be reduce by $97 \%$ and $94 \%$ when Scenario 1 and 2 was implemented in West Bandung Regency. Human death rabies can be averted approximately 28 cases from this program and the cost per death that can be averted are US\$ 7,896-10,007 cumulatively and cost per DALY averted are approximately US\$ 246-270. Human rabies could be eliminated on the second year, meanwhile dog rabies on the third year of the program. Annual vaccination program of $70 \%$ of dog population is the best option to be implemented to prevent the human cases and the economically lost from this disease. We strongly recommend the implementation of this rabies control program in West Bandung Regency.
\end{abstract} $D A L Y$

Keywords - rabies, dog, effectiveness, control program,

\section{INTRODUCTION}

Rabies still the priority zoonotic that has to be eliminated in Indonesia. Rabies caused the death around 656 people during the period 2011-2015 in Indonesia [1]. This disease not only impact on public health but also in environmental health, wildlife sectors and socioeconomic sectors. Counting rabies cost can be determined from some aspect such as the impact on livestock and working animals, on tourism, recreation and wildlife conservation and also the public health impact that can be expressed as disability-adjusted life years (DALYs) [2].

Hampson et al. [3] explained that the estimation of rabies causes 59,000 human death, over 3.7 million DALY and 8.6 billion USD economic losses annually. The largest component is due to premature death and post exposure prophylaxis (PEP). Post exposure prophylaxis will very costly in the free area with significant and unnecessary costs and unfavorable benefit [4].- In developed country, where rabies is not the main issue for domestic animals, prevention of rabies has been performed in wild animals to prevent the infection of this disease [5]. In developing country where rabies is endemic disease like in many African and Asian Country, accessibility of PEP treatment is the main burden that impact in human especially in rural area and children particularly [6].

Implementation of rabies elimination program has been developed in many rabies endemic country. This action need multisectoral collaboration such as public health sectors, animal health, environmental and also wildlife sectors. World Health Organization summarize that successful rabies control program consist of three 
pillars i.e. community participation; education, public awareness and access to mass vaccination of dogs; and access to post bite treatment [7].

In Indonesia, rabies control program has developed with One Health approach involving public health and animal health sectors. To implement this program, decision maker need the justification to obtain the effective program to eliminate or prevent rabies in that area. Cost effectiveness of rabies control program has been studied in several areas in Indonesia such as Flores island which is the rabies-endemic area in Indonesia. West Java is the one of province that still infected by certain area. To prevent the spread of the disease, rabies control program in surrounding area has to be done. The aim of this study is to demonstrate the effectiveness of rabies control program in West Bandung Regency as a threatened area in West Java Province.

\section{MATERIALS AND METHODS}

We use Rabiesecon tools, a spreadsheet tool that use mathematical model of dog and dog and dog-human rabies transmission to estimated ward of rabies [8]. West Bandung Regency is the threatened rabies area because its geographical surrounded by non-free rabies area.

We use the West Bandung Regency as setting area as the setting area with approximately 1.7 million human population in $1,311 \mathbf{k m}^{2}$ area. Cost inputs are based on their rabies control program on 2018 (Table 1). The Regency government has implemented dog mass vaccination, population control and also mass education campaign program.

TABEL 1. RABIES Data INPUTS AND ASSUMPTION IN WEST BANDUNG REGENCY ON 2018

\begin{tabular}{|c|c|c|}
\hline Program Area & Area setting & Reference \\
\hline $\begin{array}{c}\text { Square kilometers }\left(\mathrm{km}^{2}\right) \text { of } \\
\text { program area }\end{array}$ & 1,311 & (9) \\
\hline Human population & $1,710,088$ & (9) \\
\hline Humans per $\mathrm{km}^{2}$ & 1,304 & calculated \\
\hline $\begin{array}{c}\text { Human birth rate (per } 1,000 \\
\text { population) }\end{array}$ & 29.00 & (9) \\
\hline Human life expectancy & 72.0 & (9) \\
\hline $\begin{array}{l}\text { Number of humans per dog } \\
\text { (Human:Dog ratio) }\end{array}$ & 362.0 & Calculated \\
\hline Dog population & 4,724 & Calculated \\
\hline Dog birth rate (per 1,000 & 572 & 6 \\
\hline $\begin{array}{l}\text { Dog life expectancy, years } \\
\text { Number of bites per dog to } \\
\text { another dog }\end{array}$ & $\begin{array}{l}5.0 \\
2.40\end{array}$ & assumption \\
\hline Rabies $R_{0}$ Dog to Dog & 1.080 & \\
\hline $\begin{array}{l}\text { Dog-Human transmission } \\
\text { rate } \\
\text { Human deaths annually in } \\
\text { current program (at week } \\
\text { 0) }\end{array}$ & 0.0002054 & Calculated \\
\hline
\end{tabular}

\section{Intervention Option}

Three option of intervention for these models has developed. Firstly (scenario 1), no vaccination at all for all population, secondly (scenario 2) is the WHO recommendation of vaccination program that vaccine for $70 \%$ dog population with spayed and neutered program annually and lastly (scenario 3) 35\% of biannually rabies vaccination program with spayed and neutered program annually as in Table 2. Program cost was justified with the local cost that implemented in Bandung Barat Regency. We apply $3 \%$ of discount rate on this study.

TABLE II. INTERVENTION MODEL

\begin{tabular}{|c|c|c|c|}
\hline Vaccination Campaign & Scenario 1 & Scenario 2 & Scenario 3 \\
\hline $\begin{array}{c}\text { Mass vaccination } \\
\text { campaign coverage } \\
\text { levels }\end{array}$ & $0 \%$ & $70 \%$ & $35.0 \%$ \\
\hline $\begin{array}{c}\text { Frequency of } \\
\text { vaccination* }\end{array}$ & $\begin{array}{c}\text { Single/one } \\
\text { time }\end{array}$ & Annual & Biannual \\
\hline $\begin{array}{c}\text { Proportion of adult } \\
\text { female dogs spayed, } \\
\text { annually }\end{array}$ & $0.0 \%$ & $2.5 \%$ & $2.5 \%$ \\
\hline $\begin{array}{c}\text { Proportion of adult male } \\
\text { dogs neutered, annually }\end{array}$ & $0.0 \%$ & $7.5 \%$ & $7.5 \%$ \\
\hline $\begin{array}{c}\text { Probability of receiving } \\
\text { PEP, post-exposure }\end{array}$ & $50.0 \%$ & $50.0 \%$ & $50.0 \%$ \\
\hline
\end{tabular}

\section{RESULTS}

On scenario 1 of setting program, there no vaccinated given to the dog population cumulative estimation of infected dogs are 1,428 dogs in this setting area. Using the Scenario 2 and 3 that implement the vaccination program with $70 \%$ coverage levels annually and 35\% biannually (respectively) dog rabies cases will eliminate at $3^{\text {rd }}$ year of the program.
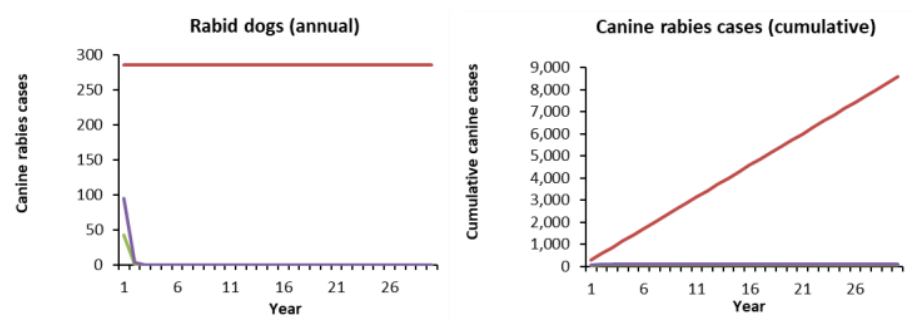

Fig.1. Canine rabies cases in the setting scenario

Human deaths from dog rabies exposure are 28 people in 5 years if no program implemented and it will be increases with time. Using scenario 2 and 3, human deaths will be averted and will be zero on $2^{\text {nd }}$ year.

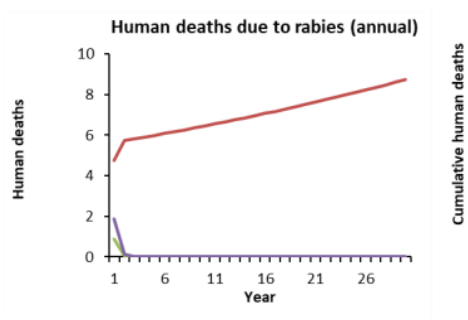

Scenario $1-$ Scenario 2

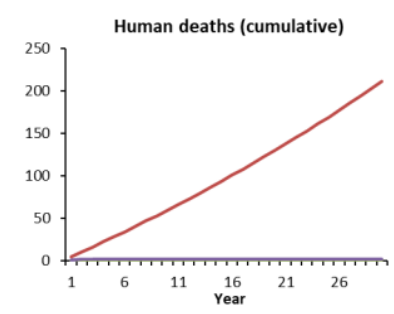

Scenario 3
Fig. 2. Human rabies cases in the setting scenario

Program cost for the scenario 2 and 3 program cost is almost the same in the implementation of scenario 2 and 3 in this study. Cumulative cost on 5 years' implementation of rabies control program will be US\$248,388 for scenario 2 and US\$ 247,132 for scenario 3. Meanwhile, cumulative cost per human death averted are US\$10,007 and US\$ 10,398, and cost per DALY averted is 270 and 290 for scenario 2 and 3 
respectively. Almost $80 \%$ of total cost of this program allocated to dog vaccination.

Table 3 Program Cost Rabies Control Program in West Java REGENCY AT 5TH YEAR

\begin{tabular}{|c|c|c|c|c|c|c|}
\hline & \multicolumn{2}{|c|}{ Scenario 1} & \multicolumn{2}{|c|}{ Scenario 2} & \multicolumn{2}{|c|}{ Scenario 3} \\
\hline & $\begin{array}{r}\text { Ann } \\
\text { ual }\end{array}$ & $\begin{array}{r}\text { Cumul } \\
\text { ative }\end{array}$ & $\begin{array}{r}\text { Annua } \\
1 \\
\end{array}$ & $\begin{array}{r}\text { Cumula } \\
\text { tive }\end{array}$ & Annual & $\begin{array}{r}\text { Cumulati } \\
\text { ve }\end{array}$ \\
\hline $\begin{array}{ll}\begin{array}{l}\text { Program } \\
(\$ \mathrm{US})\end{array} & \text { costs } \\
\end{array}$ & 0 & $\mathbf{0}$ & 47,264 & 248,388 & 47,116 & 247,132 \\
\hline $\begin{array}{l}\text { Cost per human } \\
\text { death averted) (\$US) }\end{array}$ & N/A & N/A & 7,896 & 10,007 & 7,871 & 10,398 \\
\hline $\begin{array}{l}\text { Cost per DALY } \\
\text { averted (discounted) } \\
\text { (\$US) }\end{array}$ & N/A & N/A & 246 & 270 & 245 & 290 \\
\hline
\end{tabular}

\section{DISCUSSION}

Based on our finding, rabies outbreak will appear and increase over time if no action implemented against this disease in setting area of Wes Bandung regency because of the risk from un-free neighbor area. The increase of the rabid dog will increase the risk of human death due to rabies, in accordance with previous study [10]. By implementing a program where $80 \%$ of the cost is vaccination in animal that cost approximately 10 USD per dog, it can reduce the probability of rabid dogs and human death up to $98 \%$ in 5 years. This is consistent with the previous research where if annual mass vaccination of $70 \%$ of the total number of dogs using a long-acting vaccine was the most cost- effective strategy in reducing rabies cases in dogs in Flores Indonesia [8]. If we compare with the cost of PEP (120 USD) in this study the vaccination program will be much effective against rabies disease in human and also affordable.

Our stimulation estimated that rabies can be eliminate in 3 years after the program. This finding will be achieved if the scenario 2 or 3 has implemented consistently. This finding is consistence with the previous study in Africa City that dog rabies-mass vaccination campaign achieving a coverage of least $70 \%$ will be effective to break the transmission dog rabies to humans for at least 6 years [11].

DALY as the estimation the burden of the disease can be used to prioritize the program of some disease such as rabies by the decision maker [12]. DALY was estimated using score of the years of life lost due to premature mortality and years of life lost with disability caused by the disease. Mortality rate for rabies in human almost $100 \%$ and in Indonesia the average age of date due to rabies is 10 years old with life expectancy in this country is 72 years old so the YYL of rabies based on this study is 32.13 much higher than previous study [3].

Based on this study, whereas the data that we used are the estimation such as the dog population and the estimation of the number human infected, this impact should not be underestimated. A study in South Africa using highly dynamic population shown that $70 \%$ coverage rabies vaccination is effective to maintain critical threshold of rabies infection [13]. Study in
Japan, the free rabies area, in contras said that implementation of annual vaccination of domestic dogs is very inefficient, it is probably because Japan has very low risk of rabies outbreak in past 26 years [14]. It will be very different with Indonesia which is rabies endemic area. The effective investment on preventing rabies in animals still the best option [15] against rabies and preventing human death based on this study. Using cost effectiveness of the certain program can give the picture for the stakeholder [16] to take actions against rabies especially in Indonesia.

\section{ACKNOWLEDGMENT}

We want to thank to Animal Health Division of Fisheries and Animal Husbandry Services Office of West Bandung Regency for supporting the data.

\section{REFERENCES}

[1]. Kementerian Kesehatan RI. Infodatin-Rabies-2016.pdf [Internet]. 2016. p. 12. Available from: www.depkes.go.id/download.php?file.../pusdatin/infodatin/Inf odatin-Rabies-2016.

[2]. Regea G. Archives of Preventive Medicine Review on Economic Importance's of Rabies in Developing Countries and Its Controls. Arch Prev Med [Internet]. 2017;2(1):015-21. Available from: https://www.peertechz.com/articles/reviewon-economic-importance-s-of-rabies-in-developing-countriesand-its-controls.pdf

[3]. Hampson K, Coudeville L, Lembo T, Sambo M, Kieffer A, Attlan M, et al. Estimating the Global Burden of Endemic Canine Rabies. PLoS Negl Trop Dis. ;9(4):1-20 2015

[4]. Ribadeau Dumas F, N'Diaye DS, Paireau J, Gautret P, Bourhy $\mathrm{H}$, Le Pen $\mathrm{C}$, et al. Cost-effectiveness of rabies post-exposure prophylaxis in the context of very low rabies risk: A decisiontree model based on the experience of France. Vaccine [Internet]. ;33(20):2367-78 2015. Available from: http://dx.doi.org/10.1016/j.vaccine.2015.02.075

[5]. Kemere P, Liddel MK, Evangelou P, Slate D, Osmek S. Economic analysis of a large scale oral vaccination program to control raccoon rabies. Hum Conflicts with Wildl Econ Considerations. ;(August):109-16. 2002

[6]. Knobel DL, Cleaveland S, Coleman PG, Fèvre EM, Meltzer MI, Miranda MEG, et al. Knobel DL et al. Re-evaluating the burden of rabies in Africa and Asia. Bulletin of the World Health Organization, , 83(5):360-368 2005. [7]. Dog-mediated OF. Report of the Rabies Global Conference HUMAN RABIES OF DOG-MEDIATED. 2015;

[8]. Borse RH, Atkins CY, Gambhir M, Undurraga EA, Blanton $\mathrm{JD}$, Kahn EB, et al. Cost-effectiveness of dog rabies vaccination programs in East Africa. PLoS Negl Trop Dis. ;12(5):0-1 2018.

[9]. Setyowati TIB, Machmud PB. a Study of Correlation Between Agent, Host, Environment and Vaccine Factors With Prevalence of Rabies in Indonesia 2015. Indones J Trop Infect Dis. 2018;7(1):1.

[10]. Zinsstag J, Dürr S, Penny MA, Mindekem R, Roth F, Menendez Gonzalez S, et al. Transmission dynamics and economics of rabies control in dogs and humans in an African city. Proc Natl Acad Sci U S A. 2009;106(35):14996-5001.

[11]. Coleman PG, Fèvre EM, Cleaveland S. Estimating the public health burden of rabies. Emerg Infect Dis. 2004;10(1):140

[12]. Conan A, Akerele O, Simpson G, Reininghaus B, van Rooyen J, Knobel D. Population Dynamics of Owned, Free-Roaming Dogs: Implications for Rabies Control. PLoS Negl Trop Dis. 2015;9(11).

[13]. Kwan NCL, Yamada A, Sugiura K. Benefit-cost analysis of the policy of mandatory annual rabies vaccination of domestic dogs in rabies-free Japan. PLoS One. 2018;13(12):1-18.

[14]. Shwiff SA, Brown VR, Dao TT, Elser J, Trung HX, Tien NN, 
et al. Estimating the economic impact of canine rabies to Viet Nam 2005-2014. PLoS Negl Trop Dis. 2018;12(10):e0006866.

[15]. Shwiff SA, Elser JL, Ernst KH, Shwiff SS, Anderson AM.
Cost-benefit analysis of controlling rabies: placing economics at the heart of rabies control to focus political will. Rev Sci Tech. 2018;37(2):681-9. 